\title{
A SWOT Analysis of Persian Handmade Carpet Exports
}

\author{
Seyed Fathollah Amiri Aghdaie (Corresponding author) \\ Assistant Professor, Dep.of Management \\ University of Isfahan, Isfahan, Iran \\ Tel: 98-311-793-5251Ｅ-mail: Aghdaie@mang.ui.ac.ir
}

Hosein Zare Zardeini

Industrial Management, University of Isfahan, Isfahan, Iran

E-mail: Hzare622@gmail.com

Received: July 9, 2011

Accepted: September 13, 2011

Published: January 16, 2012

doi:10.5539/ijbm.v7n2p243

URL: http://dx.doi.org/10.5539/ijbm.v7n2p243

\begin{abstract}
Since long Time Ago The Persian handmade carpet has known as symbolize of Persian art and culture, This product with several thousand years history Because of particular characteristics in production, designing quality, job creating potential and entering foreign currency has an important and strategic place among Iran's non oil export. But in recent decade decrease the share of Persian handmade carpet in foreign markets.

The goal of this research is to analyze the export of Persian handmade carpet by using the SWOT matrix. The type of this Article is descriptive- cognitive and the related information for this scope has been collected by using library resources such as books scientific journals and more over for collecting necessary data a questionnaire made by researchers have been used, statistic society of research includes a group of experts, sellers and exporters of handmade carpet in Isfahan province which we collected and analyzed their opinion through the use of SWOT matrix. Results of this research show all of the strengths, opportunities, weaknesses and threats of this industry in export.
\end{abstract}

Keywords: Persian handmade carpet, Export, SWOT matrix

\section{Introduction}

Today, the most important challenge in Iran's economy exporting of unit product and depend to the obtain incomes of petroleum. The trades of recent years in Iran show that the reliance of Iran's economy on the arisen income from selling the oil has caused the instability in export's incomes, therefore in order to reduce the dependence of economy on the single exporting of the oil and turn it to multi product in exportation, The orientation of exporting policies must be changed to the favor of non petroleum goods such as handmade carpet, obviously such activity cannot be carried unless the existing opportunities in the section of carpet be recognized and provided an operational aspect to those opportunities and in other hand we should know the difficulties of export and consider necessary strategies in order to solve them (Jafar nejad, etal, 2009).

The downward trend of Persian handmade carpet exporting during last year is one of those subjects, which have engaged the mind of many commercial responsible. Although, Iran has about percentage 40 share of the world markets and it is first in the ranking, but the carpet exportation has been faced with reduction on the value and rate of trades, while the competitor countries are increasing their share of markets by promoting the quality and quantity of their productions and finding new market (Iran customs office, 2009).

Apart from agriculture productions, handmade carpet is one of the most important products in export and it is playing a significant role in Iran economy, because it is the best and low cost method in order to create occupations, especially in rural and the underprivileged regions. Therefore with attention to above cases, we find it is very important and necessary to invest as much as possible in this field in order to improve the place of country in the world markets of handmade carpet.

\section{Persian handmade carpet}

Undoubtedly the ancient name of Iran is well known among the nations. This popularity has many cases, but the most important one is carpet. Handmade Persian carpet with several thousand years' history which is the most 
glorious ancient arts of Iranian nation has close relevance with Iranian civilization and culture (Hosseini, 2004)

Although the beginning of handmade carpet's history in Iran is from the time of Samanian kingdom (5000 years ago), But in terms of progress the two periods of Saljughian (2000 years ago ) and Safavi (700 years ago ) kingdoms, were the best time for this valuable art, women of Saljughi were intelligent \& wise in weaving the beautiful carpets. Plan and design of carpets in this era were the best among of all the times (Firozabadi, 1997)

The period of Safavi's kingdom which is very famous in growth and develop of art and trade also carpet industry finds the maximum growth and abundant carpets were exported to abroad .One of the great kings of Safavi's kingdom was Shahabbas who was really interested to all kinds of art especially carpet weaving. He established many places for carpet weaving besides of his palace in order to observe directly the work of carpet's weaver and he wants to be sure about carpets weaving and quality and its elegance, therefore because of this especial attention carpet industry has its highest development at this time (Seyf, 2001).

Eventually from the late nineteenth century with development of commercial relations between Iran, Europe and America and coming many business man and tourists to Iran, Beautiful Persian carpets allocated large part of Europe and American markets to itself and faced with unique welcome (Seyf,1990)

Persian handmade carpet in fact because of having excellent quality, nice design with different plant color, rich experience in design and dyeing is able to have an especial place in global markets. Wool, cotton and silk are the main materials used in carpet texture. Handmade carpet is a total of knots that woven together and as much as the knots be closer to each other the quality of carpet is better (Daryaee, 2007).

In this time, weaving carpet, is the main jobs of people in many provinces such as Isfahan, Kerman, Qom, Yazd and etcetera, But wool carpets of Kerman and Yazd with silk carpets of Isfahan and Qom are very famous among other carpets and because of that allocated the highest volume of export to them.

\section{Export}

Although the export of Persian carpet in not so far past allocated the first place to itself, but nowadays can hardly be among the first ten exports items of Iran.

When the export's process of Persian handmade carpet left to decrease, the activity of competing countries like Pakistan, India and China in producing and exporting handmade carpet increased, in 2006 when Iran has 5.2 percents decrease in carpets export, India 8.25 percents and Pakistan 3.24 percents have increased, although in terms of quality, none of these countries able to reach to Iran's place (Shamabadi, 2008).

Statistics issued by the Iranian customs shows that the highest volume of Persian carpet exports was in 1995 and until 1999. export process was in good condition but since 2000 to 2007 as shown in figure 1, carpet exports has had decreasing trend, this figure also shows that from 2008 carpet exports has improved conditions.

Studies concerning carpet world market shows in recent year's peoples of world because of having economic problems are very interested to buy cheap carpet, so we can see clearly that India and Pakistan with understanding the economic situation of the world increased the producing of cheap carpet and develop their share in global market, while Iran loses its market share.

Lack of attention to world economic situation and having no proper marketing plan are the causes of Persian carpet retardation but the thing which has made the most damage to Persian handmade carpet and puts its Export in Danger is its Identity in Foreign Markets which is hidden versus take carpets of competitors, for example, sometimes it happens when a buyer goes to a carpet shop in his or her country for buying a Persian handmade carpet, The seller inadvertently or intentionally introduced some carpet which are not really Persian carpet and have only Persian design and woven by Iran's competing countries such as Pakistan and India, this indecent action which only creates extra profit for the jobber seller because those carpets are more cheaper, undoubtedly makes question about the identity of Persian carpets. The buyer who thinks he has bought Persian carpet, naturally expected too much, he has heard, Persian carpets have high quality, beautiful design, stable and natural colors, therefore he or she expected to receive the goods which have those privileges versus of paying too much money, But after a few month unexpectedly observe the quality of carpet changed and this is not the one that he or she expected.

Imagine now, after all of these things what will be the reaction of the buyer, certainly becomes pessimistic to all Persian carpets and not only never buy again, that makes negative propaganda. Therefore, it is clear that the result of some seller's mistake have too much effect on worlds markets of Persian handmade carpet. So all of the persons, who are responsible regarding this industry should find reasonable solution versus these problems, in order to protect the identity of Persian carpet in global markets. 


\section{SWOT}

SWOT framework has enjoyed consistent popularity among both researchers and practitioners during the last several decades. Originally introduced in 1969 by Harvard researchers, the SWOT framework became popular during the 1970s because of its inherent assumption that managers can plan the alignment of a firm's resources with its environment. Subsequently, during the decade of 1980s, Porter's introduction of the industrial organization paradigm with his diamond models which gave primacy to a firm's external environment and added the popularity of SWOT. At the start of the twenty-first century, SWOT is alive and well as the recommended framework for case analysis in many of the leading strategic management and marketing texts (Milorad, etal, 2009).

In this method with analyzing the strengths and weaknesses as internal factors and opportunities with threats as the external factors, suggest strategies, for organizations, this strategies divide in four group such as, SO (using the strength for benefit from opportunities), WO (using the opportunities for eliminate the weaknesses), ST (using the strength for reducing threats vulnerability), WT (eliminating the weaknesses for reducing vulnerability against threats) (Nikolaou, etal, 2011).

\section{Methodology}

In this research, we analyze the opportunities, Threats, Strengths and Weaknesses in handmade carpet industry by using available empirical and library studies. Then all of the known factors come in the form of questionnaire, which made by researchers and were given to be statistical society who was fifty experts' persons in Isfahan province handmade carpet industries.

In questioner, we asked respondents make clear the rate of their agreement with expressed sentences from very high to very low (very much, much, medium, low, very low). Sentences using were about external and internal factors and were informing sentences. Like the following sentences, which the two are regarding the external factors (potential markets and copying the design by competitors, 1 and 2), and the other two are about internal factors (using traditional method in export and World famous, 3 and 4).

1) American and Europe markets provide suitable opportunity for increasing export of Persian carpet.

2) Copying of competitor from design and plant of Persian carpet threats the export of Persian carpet.

3) Old history and World famous are the strength points of Persian carpet in export.

4) Using traditional methods is the weakness points of Persian carpet in export.

In this research for analyzing, the extractive data from questionnaire have been used SPSS software and base on $\mathrm{T}$ test statistical method. The reliability of questionnaire has been evaluated based on Cronbach's alpha which the amount of that is $82 \%$, that confirms the reliability of the questionnaire.

\section{Research finding}

Initial empirical and library studies indicate seven opportunities, 6 threats, 6 strengths and 7 weaknesses in Iran's carpet industries. In order to obtain reasonable and real results, Questionnaire was designed based on these 26 factors and the Data were analyzed. Results of data analyzing are presented in table 1 and 2.

Analysis of findings related to the external factors shows that in reliability level of $95 \%$, all environmental opportunities and threats confirmed by respondents (table 1).

The Results of analysis of data related to internal factors indicated in Table 2. In addition, show that significant levels of all factors are less than $5 \%$ and in reliability level of $95 \%$, all Strength and weakness points confirmed by respondents.

\section{Discussion and Conclusion}

The results of analyzing the data given by questionnaire have determined the most important opportunities, threats, and weaknesses of Iran's carpeting industry. In this section, these internal and external factors have been compared and analysis. Then given develop strategies for the export of Persian handmade carpet.

\subsection{Treats}

$\mathrm{T}_{1}$ : decrease the price of hand mad carpet in international market.

$\mathrm{T}_{2}$ : Exporting inferior carpets with the name of Persian carpets.

$\mathrm{T}_{3}$ : Increase the producing of machine made carpets.

$\mathrm{T}_{4}$ : Recession

$\mathrm{T}_{5}$ : Copying the design and patterns of Persian carpet. 
$\mathrm{T}_{6}$ : High customs tariffs in target markets.

Technology progress in machine made carpets end other flooring production has increased producing of these products in last few years, addition to this suitable marketing and low prices of these products also out up their selling and as a result have reduced the demand of handmade carpets. Also worldwide recession and decrease the ability of consumer in buying products have reduced the demand of handmade carpet and consumers are interested to buy inexpensive carpets.

Unsound competition of some competitors has had a negative impact on Persian handmade carpet export. Copying the designs and patterns and using the name of regions that produce handmade carpet and are very famous like Esfahan, Kashan and Tabriz has had a negative impact on Persian handmade carpet name and its reputation in global market.

7.2 Opportunity

$\mathrm{O}_{1}$ : Existence of potential markets.

$\mathrm{O}_{2}$ : The interest of private sector in investment.

$\mathrm{O}_{3}$ : Government determination to develop non- oil export.

$\mathrm{O}_{4}$ : Governments political and commercial relations with other country.

$\mathrm{O}_{5}$ : Develop of electronic commerce over the world.

$\mathrm{O}_{6}$ : Government's support from foreign investment.

$\mathrm{O}_{7}$ : Technology progress.

Existence potential markets in America and Europe, Government supports of carpet exports and technology progress in spinning, designing and dying are the best environment opportunity for Iran carpeting industry. Tailored use of opportunities in environment can provide conditions for carpets production and exporting with low cost. In addition, it can help improving the level of Persian carpet in global markets.

\subsection{Strengths}

$\mathrm{S}_{1}$ : Ancient history and worldwide popularity.

$\mathrm{S}_{2}$ : Variability in production.

$\mathrm{S}_{3}$ : Skilled human resource

$\mathrm{S}_{4}$ : Desirable raw material.

$\mathrm{S}_{5}$ : High quality of products

$\mathrm{S}_{6}$ : Technical experiences in designing and dyeing.

Handmade carpet as an artistic and industrial product is rooted in Iran's history and civilization. Carpet is usually incorporated among people of the world with Iran's name.

Iran's popularity is because of its high quality and varied design. Access to expert and skilled worker and use desirable wool and natural colors lead the ability in producing beautiful and desirable carpets. Use of these strengths to utilizing opportunities and reducing the impact of threats can provide the conditions for improving and developing Persian handmade carpet exportation.

\subsection{Weaknesses}

$\mathrm{W}_{1}$ : Unfamiliarity with modern marketing methods.

$\mathrm{W}_{2}$ : the products are not conforming to the tastes and needs of consumers.

$\mathrm{W}_{3}$ : use of traditional methods in exportation.

$\mathrm{W}_{4}$ : high prices of Persian carpet.

$\mathrm{W}_{5}$ : scattering wearing workshops.

$\mathrm{W}_{6}$ : Small and non commercial weaving workshop.

$\mathrm{W}_{7}$ : Existence rust spinning and dying workshops.

Paying attention to tastes and needs of handmade carpets consumers in international market has been one of the most important challenges of Iran's carpeting in last half century. Traditional production process and not using the modern marketing methods has made producers and exporters to forget about market needs and tastes. In addition, because of that there is no coordination between their carpet's design and consumer tastes and needs, too. Another weakness of Persian handmade carpet is the price, which is high. Use of traditional methods in 
wool and color production, rusty spinning and dyeing factories has been the cause of increasing the production costs and carpet's price.

Small and scattered workshops are other weaknesses. Considering that carpet display in large exhibition and markets is one of the common methods of selling in last few years, scattered weaving workshops will not have the ability of providing a determined amount of a type, and if a design is woven in different workshop, the carpets would have different in size, color and quality, And the buyers who are wholesalers are not interested ordering from small and scattered workshop. So these factors cause the decrease of carpet export in last few years.

By comparing internal and external factors try to give some strategies for development of handmade carpet exports and results will be given in table 3 .

Comparing Iran's environmental opportunities and strengths can give new strategies in using environmental opportunities through strengths. According to Iran's popularity and ability in producing desirable carpets and because of suitable markets, communication between internal and foreign companies in carpeting industries and producing desirable and varied carpet, can increase Iranian export. In addition, external companies' participation in carpeting industry has entered modern technology and methods into Iran, and help decreasing production costs. Use of political and commercial relation of Iran in carpet export, and government cooperation in introducing producers and Iranian carpet businessperson to other countries can help increasing Persian carpet export too. In addition, tailored political relations between Iran and other countries has raised the security of investment in Iran and provided condition for foreign companies' participation and attracting foreign investment.

Comparing strength and threat points in Iran's carpeting shows that Iranian officials should advertize and inform people about its name, features, quality and excellence in target markets in order to preventing competitors copying and their exporting with the name of Iran. They can protest against competitors copying and record Persian carpets designs and patterns by registering in copyright organization. Producers should use experiences and knowledge of designer and exports in designing low-price carpets and using appropriate and chip methods so they can decrease carpet price and negative impacts of recession. Another beneficial way in decreasing carpet price is increasing efficiency in raw material production factories and weaving workshop. Efficiency can reduce most of production costs and it cause to produce carpet with lower price.

Comparing opportunity and weaknesses of Iran is carpeting industry shows that tailored use of opportunity can help removing its weaknesses. Producer should try to use technology and mother method in recognize tastes and needs of target markets and produce their products with considering consumer tastes and needs. An adaptation product with consumer tastes and needs increase products sells and develop exports. External and internal cooperation in marketing and carpet exports, use of electronics methods in marketing and selling and exporter familiarity with modern marketing and exportation methods can help developing export. Producing should try to use modern technologies in producing raw material and modern methods in dying and designing in order to decrease production costs and products' price. Government support of external and internal investment cooperation in carpeting make exports increased. Cooperation of external and internal investment investors in establishing large production units and centralizing production workshops not only can reduce production costs but also can producing amounts of common carpets.

One of the weaknesses of Iran's carpeting is rusty weaving and dyeing workshops and factories in this industry. Producing row materials by this factories decreases quality of carpets and increase the cost of raw materials. Efforts of carpeting industry Officials in order reconstruction these factories and replacing their equipment with modern equipment can help producing cheap and high quality carpets. Tailored managing of production costs and producers efforts in reducing operating costs put up Iran's ability in producing cheap carpets and export to global markets.

Development of sIran is carpeting exportation needs effort of producers, exporters and government. Appropriate cooperation of them can develop this industry and increase its exports. Most of weaknesses and threats of carpeting industry are because of inappropriate price and marketing. Carpeting industry invigoration in two sectors can help this industry.

\section{References}

[Online] Available: http://fa.tpo.ir/ParsDesign/files/DataCategory/Items/1058.pdf

[Online] Available: http://fa.tpo.ir/ParsDesign/files/DataCategory/Items/920.pdf

Bilgin, Mehmet Huseyin, Demir, Ender, Lau, Marco Chi Keung, Kin-Man To, Chester and Zhang, Zhi-Ming. (2011). The Turkish handmade carpet industry: an analysis in comparison with select Asian countries. Journal of the Textile Institute, No.1, pp. 1-13. 
Cameron, S., \& Khair-uz-zaman. (2006). Export supply function estimates for the Pakistan carpet industry. The Pakistan Development Review, Vol.45, No.4, pp. 1287-1297.

Carolina Duarte, Lawrence P. Ettkin,Marilyn M. Helms and Michael S. Anderson. (2006). The challenge of venezuela: a SWOT analysis. $S, C R$, Vol.16, No. $3 / 4$.

Çitlak, Ü. Candan, C., and Berkalp, Ö. B. (2001). Market Research for the Turkish Tufted Carpet Sector. Journal of the Textile Institute, Vol. 92, No. 1, pp. 19 -30. http://dx.doi.org/10.1080/00405000108659592

Clark, Andre. (2011). Educators vs. entrepreneurs: traits and bias in the teaching of SWOT. Journal of Further and Higher Education, No.1, pp. 1-12.

Clark, J. Dana. (2008). ormulating Strategic Marketing Direction for a Second-Tier Convention Center: The Hickory (North Carolina) Metro Convention Center. Journal of Convention \& Event Tourism, Vol. 9, No. 2, pp. 148 -160. http://dx.doi.org/10.1080/15470140802192727

Coman, Alex and Ronen, Boaz. (2009). Focused SWOT: diagnosing critical strengths and weaknesses. International Journal of Production Research, Vol. 47, No. 20, pp. 5677-5689. http://dx.doi.org/10.1080/00207540802146130

Daryaee, N. (2007). Beauty in Iran's Carpet. Journal of Carpets Science Association, Vol.2, pp. 25-35.

Dierk Herzer and Felicitas Nowak-Lehnmann D. (2006). What does export diversification do for growth? An econometric analysis. Applied Economics, Vol.38, pp.1825-1838. http://dx.doi.org/10.1080/00036840500426983

Diskiene, Danuta, Galiniene, Birute and Marčinskas, Albinas. (2008). A strategic management model for economic development. Technological and Economic Development of Economy, Vol. 14 No. 3, pp. 375-387. http://dx.doi.org/10.3846/1392-8619.2008.14.375-387

Firozabadi, D. (1997). Causes of Iran's loss share in global carpet market in compare with competitors. Thesis, Ferdowsi University of Mashhad, Mashhad, Iran

Hill, T., and R. Westbrook. (1997). SWOT analysis: It's time for a product recall. Long Range Planning, Vol. 30, No. 1, pp. 46-52. http://dx.doi.org/10.1016/S0024-6301(96)00095-7

Hosseini,M. (2004). Globules Structure of handmade Carpet Markets and Iran's export target markets. Quarterly Journal of Business, Vol. 30, pp 83-114.

Houben, G., Linie, K. and Vanhoof, K. (1999). A knowledge-based SWOT-analysis system as an instrument for strategic planning in small and medium sized enterprises. Decision Support Systems, Vol. 26, No. 2, pp. 125-135. http://dx.doi.org/10.1016/S0167-9236(99)00024-X

Jafar nejad, Ahmad, Sajadipanah ahmad and Ghashlajoee mahdi. (2009). The study of barriers and providing strategies in order to use ecommerce in development of Persian carpet exports. Quarterly Journal of Business, Vol.52, pp.11-34.

Jesús Arteaga-Ortiz and Rubén Fernández-Ortiz. (2010). Why Don’t We Use the Same Export Barrier Measurement Scale? An Empirical Analysis in Small and Medium-Sized Enterprises. Journal of Small Business Management, Vol. 48, No. 3, pp. 395-420. http://dx.doi.org/10.1111/j.1540-627X.2010.00300.x

Julian, C. C., and Z. U. Ahmed. (2005). The Impact of Barriers to Export on Export Marketing Performance. Journal of Global Marketing, Vol. 19, No. 1, pp. 71-93. http://dx.doi.org/10.1300/J042v19n01_05

Kuo-liang L, Shu-chen L. (2008). A fuzzy quantified SWOT procedure for environmental evaluation of an international distribution centre. Inf Sci, Vol. 178, pp. 531-549. http://dx.doi.org/10.1016/j.ins.2007.09.002

Lance Eliot Brouthers, George Nakos, John Hadjimarcou and Keith D. Brouthers. (2009). Key Factors for Successful Export Performance for Small Firms. Journal of International Marketing, Vol. 17, No. 3, pp. 21-38. http://dx.doi.org/10.1509/jimk.17.3.21

Leonidas C. Leonidou. (2004).An Analysis of the Barriers Hindering Small Business Export Development. Journal of Small Business Management, Vol. 42, No. 3. Pp.279-302. http://dx.doi.org/10.1111/j.1540-627X.2004.00112.x

Liu, F., Maher, A. P., Lappage, J., and Wood, E. J. (2002) .The Measurement of the Tuft-withdrawal Force in Machine-made and Hand-knotted Carpet. Journal of the Textile Institute, Vol.93, No.3, pp. 276 -282. http://dx.doi.org/10.1080/00405000208630569

Margles, Shawn W., Masozera, Michel, Rugyerinyange, Louis and Kaplin, Beth A. (2010). Participatory Planning: Using SWOT-AHP Analysis in Buffer Zone Management Planning. Journal of Sustainable Forestry, 
Vol. 29, No. 6, pp. 613- 637. http://dx.doi.org/10.1080/10549811003769483

Mbachu, Jasper and Frei, Marcel. (2011). Diagnosing the strategic health of an organization from SWOT analysis results: case study of the Australasian cost management profession. Construction Management and Economics, Vol. 29, No. 3, pp. 287-303. http://dx.doi.org/10.1080/01446193.2010.547865

Menon A. (1997). Envirpreneurial marketing strategy: the emergence of corporate environmentalism as marketing strategy. J Mark, Vol.61, pp.51-67. http://dx.doi.org/10.2307/1252189

Milorad M. Novicevic, Michael Harvey, Chad W. Autry and Edward U. (2009). Dual-perspective SWOT: a synthesis of marketing intelligence and planning. Marketing Intelligence \& Planning, Vol. 22, No. 1, pp. 84-94.

Miyazaki, Yosuke and Numata, Hideharu. (2010). Exhibition of circannual rhythm under constant light in the varied carpet beetle Anthrenus verbasci. Biological Rhythm Research, Vol. 41, No. 6, pp. 441 -448. http://dx.doi.org/10.1080/09291010903411443

Naroditskaya, Inna. (2005). Azerbaijani Mugham and Carpet: Cross-Domain Mapping. Ethnomusicology Forum, Vol.14, No.1, pp. 25-55. http://dx.doi.org/10.1080/17411910500088361

Nigel Piercy \& William Giles. (1989). Making SWOT Analysis Work. Marketing Intelligence \& Planning, Vol. 7, No.5/6, pp.5-7. http://dx.doi.org/10.1108/EUM0000000001042

Nikolaou EI \& Evangelinos KI. (2010). A SWOT analysis of environmental management in Greek mining and mineral industry. Resour Policy, Vol. 35, No. 3, pp. 226-234. http://dx.doi.org/10.1016/j.resourpol.2010.02.002

Panagiotou, G. (2003). Bringing SWOT into focus. Business Strategy Review, Vol. 14, No. 2, pp. 8-10. http://dx.doi.org/10.1111/1467-8616.00253

Pickton, D. W., \& Wright, S. (1998). What's SWOT in strategic analysis. Strategic Change, Vol.7, pp. 101-109. http://dx.doi.org/10.1002/(SICI)1099-1697(199803/04)7:2<101::AID-JSC332>3.0.CO;2-6

Pourdeyhimin, B., Xu, B., \& Wehrle, L. (1994). Evaluating carpet appearance loss: Periodicity and tuft replacement. Textile Research Journal, Vol. 64, No.1, pp. 21-32. http://dx.doi.org/10.1177/004051759406400103

Prahalad, C.K., and Hamel, G. (1990). The core competence of the corporation. Harvard Business Review, No3, pp. 79-91.

Presley, A. (1997). Evaluation of carpet appearance loss: Structural factors. Textile Research Journal, Vol. 67, No.3, pp.174-180.

Rudner, Martin. (2010). The Modernization of Iran and the Development of the Persian Carpet Industry: The Neo-Classical Era in the Persian Carpet Industry,1925-45. Iranian Studies, Vol.44, No.1, pp.49 - 76. http://dx.doi.org/10.1080/00210862.2011.524491

Seyf, A. (1983). Silk Production and Trade in Iran in the Nineteenth Century. Iranian Studies, Vol.16, No.1-2, pp.51-71. http://dx.doi.org/10.1080/00210868308701605

Seyf, A. (1990). Carpet manufactures of Iran in the nineteenth century. Middle Eastern Studies, Vol. 26, No. 2, pp. 204 -213. http://dx.doi.org/10.1080/00263209008700815

Seyf, A. (1992). Carpet Trade and the Economy of Iran, 1870-1906. Journal of the British Institute of Persian Studies.

Seyf, A. (2001). Iranian Textile Handicrafts in the Nineteenth Century: A Note. Middle Eastern Studies, Vol.37, No.3, pp. 49 -58. http://dx.doi.org/10.1080/714004403

Seyf, A. (2001). The Modernization of Iran and the Development of the Persian Carpet Industry: The Neo-Classical Era in the Persian Carpet Industry, 1925-45. Iranian Studies, Vol.44, No. 1, pp. 49-76.

Shamabadi, M. (2008). Iran's Carpet Export Marketing: analysis of Factors and pathology review. Quarterly Journal of Business, Vol.43, pp.1 - 34.

Shinno, H., Yoshioka, H., Marpaung, S., and Hachiga, S. (2006). Quantitative SWOT analysis on global competitiveness of machine tool industry. Journal of Engineering Design, Vol. 17, No. 3, pp. 251- 258. http://dx.doi.org/10.1080/09544820500275180

Srivastava, S., and Goswami, K.K. (2007). Handmade carpets: The potential for socio-economic growth. The Innovation Journal: The Public Sector Innovation Journal, Vol. 12, No.2, Article 5.

Stephanie A. Watson and Mary M. Warnock. (2003). Comparative Analysis between Recycled and Newly Manufactured Carpets. Family and Consumer Sciences Research Journal, Vol. 31, No. 4, pp. 425-441. http://dx.doi.org/10.1177/1077727X03031004005 
Tuck Cheong Tang. (2006). New evidence on export expansion, economic growth and causality in China. Applied Economics, Vol.13, pp.801-803.

Valentin, E.K. (2001). SWOT analysis from a resource-based view. Journal of Marketing Theory and Practice, Vol. 9, No. 2, pp. 54-68.

Weihrich, H. (1982). The TOWS matrix - a tool for situational analysis. Journal of Long Range Planning, Vol. 15 , No. 2 .

Y. K. Ip and L.C. Koo. (2004). BSQ strategic formulation framework A hybrid of balanced scorecard, SWOT analysis and quality function deployment. Managerial Auditing Journal, Vol. 19, No. 4, pp.533-543. http://dx.doi.org/10.1108/02686900410530538

Table 1. Result of $\mathrm{T}$ test for Opportunities and Treats

\begin{tabular}{|l|lll|}
\hline Opportunity, Treat & $\mathrm{M}$ & $\mathrm{T}$ & sign \\
\hline Existence of potential markets. & $3 / 61$ & $2 / 524$ & $0 / 0032$ \\
The interest of private sector in investment. & $3 / 95$ & $0 / 746$ & $0 / 0002$ \\
Government determination to develop non- oil export. & $3 / 2$ & $0 / 892$ & $0 / 0007$ \\
Governments' political and commercial relations. & $3 / 97$ & $0 / 826$ & $0 / 0004$ \\
Develop of electronic commerce. & $3 / 35$ & $0 / 0058$ & $0 / 0058$ \\
Government supports of foreign investment. & $3 / 9$ & $0 / 669$ & $0 / 001$ \\
Technology progress. & $3 / 12$ & $0 / 58$ & $0 / 0027$ \\
Decrease the price of hand mad carpet. & $3 / 63$ & $2 / 430$ & $0 / 0005$ \\
Increase the producing of machine made carpets. & 3.85 & 1.055 & $0 / 005$ \\
Recession. & 3.41 & 1.604 & $0 / 00$ \\
Exporting inferior carpets with the name of Persian carpets. & 3.544 & 2.245 & $0 / 002$ \\
Copying the design and patterns of Persian carpet. & 3.471 & 1.531 & $0 / 00$ \\
High customs tariffs in target markets. & 3.485 & 2.029 & $0 / 00$ \\
\hline
\end{tabular}

Table 2. Result of $\mathrm{T}$ test for Strengths and Weaknesses

\begin{tabular}{|l|ccc|}
\hline \multicolumn{1}{|c|}{ Strength, Weakness } & $\mathrm{M}$ & $\mathrm{T}$ & sign \\
\hline Ancient history and world-wide popularity. & $3 / 61$ & $1 / 09$ & $0 / 030$ \\
Variability in production. & $3 / 95$ & $0 / 9$ & $0 / 023$ \\
Skilled human resource. & $3 / 2$ & $0 / 99$ & $0 / 003$ \\
Desirable raw material. & $3 / 97$ & $2 / 2$ & $0 / 000$ \\
High quality of products. & $3 / 35$ & $0 / 992$ & $0 / 031$ \\
Technical experiences in designing and dyeing. & $3 / 9$ & $0 / 894$ & $0 / 000$ \\
Unfamiliarity with modern marketing methods. & $3 / 12$ & $0 / 058$ & $0 / 0006$ \\
Non coordination between produce and consumer needs. & $3 / 471$ & $0 / 969$ & $0 / 0024$ \\
Traditional methods in exportation. & $3 / 485$ & $1 / 58$ & $0 / 0048$ \\
High prices. & 3.673 & $1 / 758$ & $0 / 000$ \\
Scattering wearing workshops. & 3.676 & $0 / 207$ & $0 / 016$ \\
Small and non commercial wearing workshop. & 3.441 & $2 / 161$ & $0 / 001$ \\
Rust spinning and dying workshops. & 3.674 & $1 / 583$ & $0 / 008$ \\
\hline
\end{tabular}


Table 3. SWOT matrix

\begin{tabular}{|c|c|c|}
\hline & Strengths & weaknesses \\
\hline & S1 S2 S3 S4 S5 S6 & W1 W2 W3 W4 W5 W6 W7 \\
\hline opportunity & $\mathrm{SO}$ & WO \\
\hline $\begin{array}{l}\mathrm{O} 1 \\
\mathrm{O} 2 \\
\mathrm{O} 3 \\
\mathrm{O} 4 \\
\mathrm{O} 5 \\
\mathrm{O} 6 \\
\mathrm{O} 7\end{array}$ & $\begin{array}{l}\text { Exporting varied and high quality carpet } \\
\text { to America and Europe markets. } \\
\text { Government cooperation in introducing } \\
\text { products and business man to other } \\
\text { country. } \\
\text { Cooperation of private sector and foreign } \\
\text { investors in produce hand mad carpet. }\end{array}$ & $\begin{array}{l}\text { Internal sectors cooperation in marketing and export. } \\
\text { Foreign companies cooperation in marketing and export. } \\
\text { Use of electronic method marketing and export. } \\
\text { Use of external and private sectors investment in raw } \\
\text { material production. } \\
\text { Making large waving workshop in a foreign investment } \\
\text { and cooperation. } \\
\text { Centralizing weaving workshops in an area with external } \\
\text { investment and private sector. } \\
\text { Use of modern technologies in carpeting and raw } \\
\text { material production. } \\
\text { Coordination design and patterns carpet with tastes and } \\
\text { needs of consumers. } \\
\text { Exporters' familiarity with modern marketing and export } \\
\text { method. }\end{array}$ \\
\hline threats & ST & WT \\
\hline $\begin{array}{l}\mathrm{T} 1 \\
\mathrm{~T} 2 \\
\mathrm{~T} 3 \\
\mathrm{~T} 4 \\
\mathrm{~T} 5 \\
\mathrm{~T} 6\end{array}$ & $\begin{array}{l}\text { Suitable advertising and informing to } \\
\text { target markets. } \\
\text { Use of expert and designer knowledge in } \\
\text { utilizing good methods for production. } \\
\text { Record the patterns and design } \\
\text { Increasing efficiency }\end{array}$ & $\begin{array}{l}\text { Reducing production costs. } \\
\text { Replacement of rusty factories producing raw materials. }\end{array}$ \\
\hline
\end{tabular}

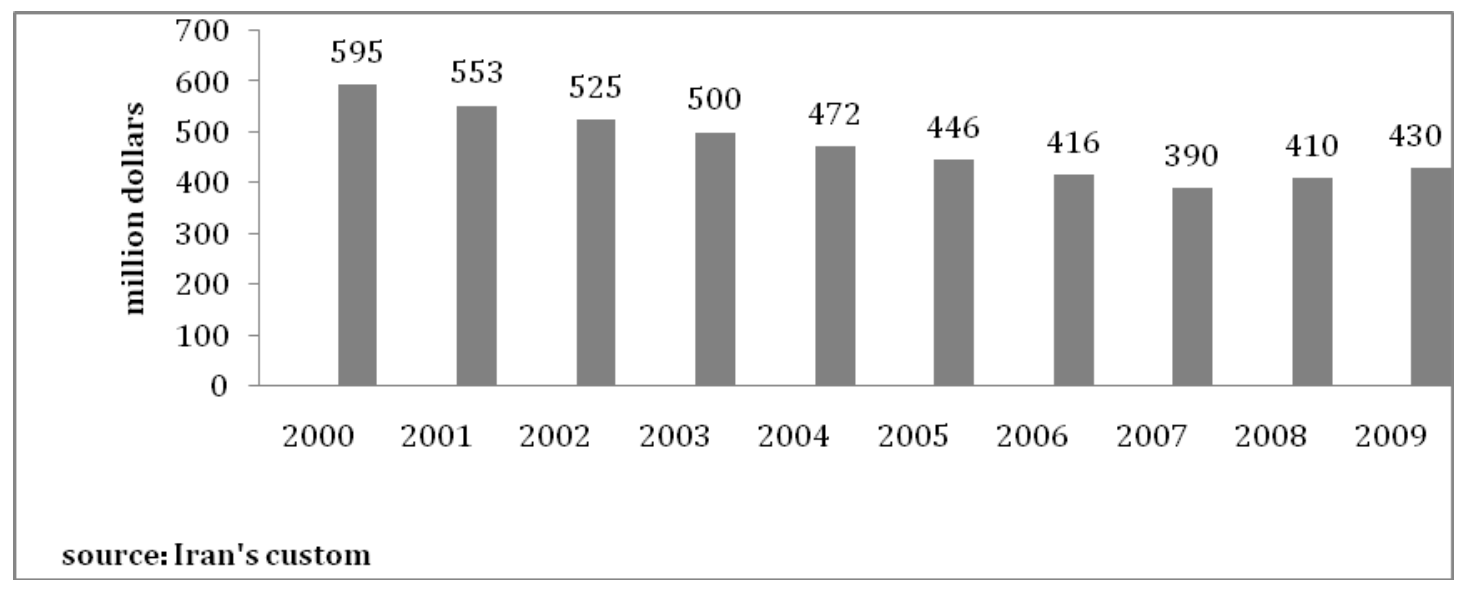

Figure 1. Persian handmade carpet export (2000-2009) 